Article

\title{
Hereditary Ecclesiae and Domestic Ecclesiolae in Medieval Ragusa (Dubrovnik)
}

\author{
Matko Matija Marušić(D) \\ Faculty of Humanities and Social Sciences, University of Rijeka, HR-51000 Rijeka, Croatia; \\ matkomatijamarusic@gmail.com
}

Received: 2 October 2019; Accepted: 14 December 2019; Published: 20 December 2019

check for updates

\begin{abstract}
The present paper explores domestic devotional practices in Ragusa (modern day Dubrovnik) from the late-thirteenth through the fourteenth and fifteenth centuries. Considering that important advancements in the understanding of domestic devotions in major Mediterranean cities have recently been made-particularly in Venice-the scrutiny of Ragusan sources enables further reflections on the same phenomena in minor Adriatic centres. Considering the paucity of preserved objects, and the fact that no late medieval domestic space of that time has survived in Dubrovnik, one must turn to archival sources to answer questions pertaining to the arrangements and uses of spaces of domestic worship. Three aspects are analysed here: privately owned chapels-adjoined to the dwellings of urban nobility, prayer areas and holy images inside the houses, and relics in the possession of individuals. In light of its source-driven approach, a significant part of this paper is devoted to the issue of the terminology of devotional props in contemporary documents. On a more general level, the paper aims at showing how, although no direct evidence of domestic devotional practices survives (such as in-depth textual evidence), all indications suggest that it was a deeply family-centred matter. Accordingly, particular attention is paid to the city's most prominent families, such as Volcassio, Volzio and Sorgo. Finally, the evidence presented in this paper, gathered from both published and unpublished sources, offers valuable material for reflections on the spatial arrangements of domestic devotional spaces, not necessarily confined to the members of a single household, but, through hereditary rights, tied to specific lineages.
\end{abstract}

Keywords: medieval Ragusa; domestic devotion; devotional triptychs; ecclesiola; domestic chapel; Holy-Sepulchre chapels; jus patronatus; privately owned relics

\section{Introduction}

Valuable advancements have recently been made in the understanding of domestic devotion, both in terms of the wide variety of holy objects in homely settings, and their use in devotions (Kasl 2004; Webb 2005; Cooper 2006; Nalle 2008; Kolpacoff Deane 2013; Baldissin Molli et al. 2018). The studies have revealed a rich domestic culture of households that has previously gone unnoticed in favour of the concept of (medieval) homes as strictly secular spaces. In tackling this presumption, the interest of scholars turned to major cities, so exemplary studies were carried out for fifteenth- and sixteenth-century Florence (Lydecker 1987; Schmidt 2005; Mattox 2006). Initial endeavours aimed at investigating more expected forms of domestic devotion, such as the construction of household chapels and domestic altars, yet the complexity of scrutinising these aspects of medieval homes lies in the fact that a range of objects in everyday use could have possessed religious qualities (Musacchio 2000; Morgan 2017, pp. 215-18; Howard et al. 2017).

Sources relating to this topic regarding Venice (Morse 2007, 2013a), furthermore, have painted a rich picture of the influx of religion in the city's case, pointing to the multifaceted range of devotional props of various iconographies and settings (Morse 2007, p. 184). Interest in these topics is continuously 
growing, and the second wave of studies tends to overcome the focus on the most prominent cities by paying closer attention to lesser-studied regions. In the interest of furthering this debate, the desiderata of these studies aims at offering nuanced insights into the general and specific phenomena of certain cities and regions, which could then be compared cross-regionally, and occasionally, cross-confessionally, as well (cf. Bacci 2018).

A substantial body of documents relating to study of medieval and early modern domestic devotional art in the cities on the eastern shore of the Adriatic have been published, but these have rarely been considered in the light of practices of household piety. ${ }^{1}$ A convenient place to start is Ragusa (modern day Dubrovnik), given that the city archives store hundreds of documents (either contracts, last wills or inventories of household goods) mentioning images in the broader sense of the word. These are consistently referred to as anconae or iconae and, hence, are not necessarily "icons" and not exclusively panel paintings. These documents-the vast majority of which refer to the images in a domestic context-were collected and edited in the early 1950s (Tadić 1952, vols. I and II). How frequently these pious domestic paintings were in inventoried households is hard to tell, due to the lack of extensive quantitative research on the subject (although it has been estimated that ninety percent of Venetian households possessed at least one devotional image, cf. (Morse 2007, pp. 163-65)). Finally, Dubrovnik's medieval and early modern domestic architecture is fairly well researched-including the interiors of homes_-but the sacred space within them has been left underexplored (cf. Grujić 2013).

This paper, accordingly, draws on the research carried out for other (mostly Italian) cities, aiming to reconstruct the range of domestic devotional spaces and objects in late medieval Ragusa. Considering the paucity of devotional objects preserved, this can only be done through an attentive reading of archival sources, which are abundant in number but scant in description of domestic devotional props. In this sense, one is inevitably faced with the problem of terminology in medieval notary documents, so a significant part of the paper is devoted to this important issue. Of particular interest here, however, is not the typology of devotional objects per se, but the question of their enshrinement in houses, as well as their role in the life of their beholders, and, more specifically, in the context of family values of that time. This paper, therefore, tries to scrutinise sources on the material culture of domestic devotion, as well as analyse indirect evidence on the practices of domestic piety, most notably the iconography of holy images. The paper is divided into three sections devoted to freestanding private chapels, indoor devotional places (in both well-off and ordinary households), and privately owned relics, respectively. Such an approach aims at investigating the "local religion" (French 2014) of medieval Dubrovnik through the examination of sources on the appearances and audiences of domestic chapels and household shrines-key places of everyday spiritual life.

\section{Freestanding Chapels of Private Foundations and Their Domestic Setting}

The most opulent form of domestic devotion was the ownership of a chapel with the bishop's concession to hold masses. This form of piety was restricted to the highest ranks of society, which could afford such oratories to be built next to their mansions. As can be deduced from the sources, this was a custom of earlier centuries (the first recorded examples in Dubrovnik date from the early middle ages), which was to die out by the end of the fifteenth century. Moreover, such private chapels were first and foremost a matter of the urban fabric, given that free space inside the city walls was restricted. The later chapels (starting from the late fourteen to early fifteenth century), therefore, were more often constructed inside the houses themselves, or, as we shall see, outside the city walls.

The earliest example that will be discussed is that of the Volcassio family, Pasqua (d. 1293) and Damian (d. 1295), sons of Vukas. The two brothers were arguably the most prosperous Ragusans at

1 A notable exception are the reflections on medieval devotional culture of the city of Kotor, in modern day Montenegro (Živković 2016). Apart from the documents on medieval Ragusa, which will be analysed in this paper, sources have been gathered for Zadar, and briefly discussed in (Hilje 2000). For discussion of fifteenth-century prayer books in Dubrovnik, mostly regarding their dating and decoration, see (Prijatelj Pavičić 2011). 
the close of the thirteenth century (Vekarić 2012, p. 339; Benyovsky Latin and Ledić 2014, pp. 13-15), and their testaments contain detailed accounts of household chapels. Pasqua's last will reveals that he was responsible for the construction of the Trinity chapel, adjacent to his houses. Although fully constructed, the chapel lacked an official consecration at the time of Pasqua's death, so this task was assigned to epitropi (testamentary executors). As articulated in the text of the testament, the chapel was to be supplied with liturgical utensils and a missal, both to be used daily whilst the commissioner's wife Dessa was still living. ${ }^{2}$ After her death, the funds for the church were to be obtained from the lease of his properties and administered by the city's treasurers (which were responsible for collecting and distributing the rent, according to the testament). ${ }^{3}$ The right of patronage (jus patronatus) of the Trinity chapel, as specified in Pasqua's testament, was hereditary. ${ }^{4}$

Pasqua's brother Damian made similar arrangements for a chapel erected on his private terrain, similarly adjoining his house..$^{5}$ The titular of the chapel is not explicitly stated in his testament, yet it is reported that it was erected to honour God Almighty, Virgin and All Saints. This chapel was not consecrated by the time of Damian's death, and his last will does not reference any liturgical utensils for serving mass. The funds for its upkeep were procured through the rent of his house and shops in Ragusa, and (if needed) a house in Venice; the sum of money bequeathed for the chapel corresponded to 31 perpers, of which 25 were destined to Franciscan friars who were responsible for saying daily mass, while six perpers were suffice to supply the chapel with candles, and ensure its constant illumination by oil lamps. ${ }^{6}$ However, at the time of his death, Damian was not confident that the friars would carry out their appointed duty, so he suggested an alternative: if friars refused to say a daily mass, his epitropi were obliged to procure a chaplain to regularly celebrate mass for 25 perpers-that is, for an equal sum given to the friars. In case no priest could be found for day-to-day service, three or four masses could be said by the priest (for five perpers) and masses on other days could be celebrated by the friars (for 20 perpers, instead of 25 for seven masses). Regardless, the sum of the service in the chapel would not exceed 25 perpers.

Damian was particularly close to the friars; they are at the top of the list of his testamentary bequests, and he ordered his tomb monument to be erected in their church. ${ }^{7}$ Although, on his deathbed, Damian was not sure whether the friars would celebrate mass, his concerns were unnecessary, given that, almost a century later, in 1383, they were still in charge of the chapel. In the proclamation of the sale of two shops in Ragusa and half of a house, in the contrada of Sancti Maphey de Rivealtis in Venice, the levies on these real estates are listed, among which were one perper and one gross pro oleo capelle Damiani de Volcassio, and six perpers fratribus minoribus pro officiando cappellam Damian de

2 Item volo quod debeat (epitropi, op.a.) sacrari ecclesia sancte Trinitatis quam feci (cancell. laborari; edificari) iuxta domus meas pro anima mea et patris et matris mee et omnium meorum mortuorum. Et debeant fieri in dicta ecclesia paramenta et calix de argento et liber missalis et debeat celebrari missa in dicta ecclesia omni die in vita uxoris mee. (. . . ) (Čremošnik 1951, p. 230).

3 On the role of the city's treasurers, see (Lonza 2012, pp. 33-35).

4 Et volo et ordino quod ista predicta ecclesia numquam debeat esse in hereditario (Čremošnik 1951, p. 230).

5 Ordino quod ecclesia mea quam hedificari feci in territorio meo juxta domum meam propriis meis expensis ad honorem et reverentiam Dei Omnipotentis et beate Marie Virginis et Omnium Sanctorum pro salute (anime mee) ac patris et matris mee et aliorum meorum tam vivorum quam defunctorum, debeat officiari a fratribus minoribus, qui cotidie dicant unam missam in eadem ecclesia. Et missam ibi cellebraret ... pro salute anime mee et omnium predicatorum inperpetuum. (... ) Et volo et ordino, quod pitropi mei, qui per (tempora fuerint) de conductura seu pensione domus mee, que est in campo, debeant extrahere et accipere perperos XXXI annuatim. De quibus yperperis volo, quod pitropi mei debeant dare predicti fratribus minoribus pro officio dicte ecclesie mee yperperos XXV annuatim. Et sex yperperos residuos a predictis debeant dare iste ecclesie ... pro luminaribus scilicet oleo et candellis. Qui si ipsi fratres minores nollent dictam ecclesiam pro aliquo modo quo dictum est officiare, volo quod dicti pitropi mei inveniant unum honestum sacerdotem qui dicam debet cotidie officiare, cui sacerdoti de illis viginti quinque yperperis ( ... ) voluerit officiare ecclesiam meam predictam solummodo quatuor diebus in qualibet epdamada dicendo missam in eadem ecclesia. Volo quod ipsi fratres minores habeant de conductura domos mee predicte yperperos viginti de illis yperperis viginti quinque supradictis. Et pro residuis tribus diebus epdomade, in quibus unus sacerdos bonus et honestus debeat dictam ecclesiam officiare, dentur eidem sacerdoti quinque yperperi residui a predictis pro illis triebus diebus. Et volo, quod dicta ecclesia mea deveniat ad aliquem clericum eciam si esset de domo mea tam secundum jus patronatus quam secundam aliquam consuetudinem sicut superius ordinatum est. (Lučić 1993, p. 279).

6 Around 1300, one perper corresponded to twelve grossi, whereas several dozen perpers were an adequate sum for a wooden house; see (Živković 1985, pp. 36-37).

7 sepulturam meam eligo apud fratres minores de Ragusio (Lučić 1993, p. 279). 
Volcasso (DADU, Vend. Canc., 4, fol. $4 \mathrm{r}$ ). ${ }^{8}$ Therefore, even though the sums of the bequests do not match perfectly, the real estate sold in 1383 was the same one owned by Damian. More importantly, the chapel in question was still called by the name of its founder and, according to his wish, continued to be served by Franciscans (whether this was on a daily basis cannot be established by existing documentation). The same document, moreover, refers to the chapel as capella S. Marie de Volcasso (Vend. Canc., 4, fol. 3v), which is the first and only mention of its dedication. ${ }^{9}$ Later records, from 1422, attest that the chapel of his brother, Pasqua's Trinity chapel, was served by the friars as well, at the wish of his son, Matthew (d. before 1340). ${ }^{10}$

The evidence of the brothers' chapels reveals a great deal about them, but it leaves us with unanswered questions. Does the fact that both chapels were contiguous to the dwellings (and that they were hereditary) make them the Volcassio brothers' "private" chapels? It is beyond doubt that these sacred buildings perpetuated the memory of their founders and endowers, yet their original spatial context and use is far from certain. One is left wondering whether they were connected to the brothers' houses by internal doors, or if there was but one entrance, from the (public) street. Moreover, it is not known if these chapels were used exclusively by the members of the owners' household, or if they were public oratories, also frequented by the common congregation of the neighbourhood. In the absence of other information, we might turn to a later (seventeenth-century) situation in the former Sorgo manor (from the nineteen century, Bishop's palace). This lavish patrician house adjoined the early medieval church of Saint Cosmas and Damian, likely dating from the eleventh century (Fisković 1997). The main entrance to the church was from the public space, while the interior of the house communicated with the church through an empora (Figure 1), located just above its main altar (Belamarić 2018, pp. 28, 35). If this was, indeed, a corresponding situation to that of the much earlier Volcassio chapels, than these two early structures (referred to in testaments as "churches", yet in later sources as "chapels"), could have been both "private"/"domestic" and open to the public. The fact that they possessed a missal, and that the search for a chaplain was of prime importance to their commissioners, confirm that the edifices in question differed little from other cities' churches.

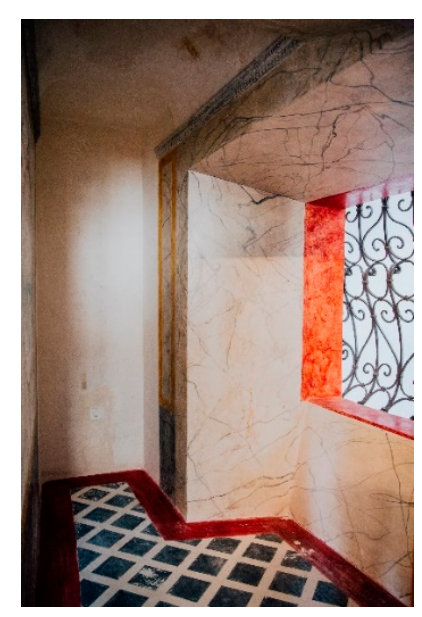

Figure 1. Empora in the Bishop's palace (former Sorgo manor); the opening with shutters is located just above the main altar of Saint Cosmas and Damian church, Dubrovnik (photo by Dean Tošović).

8 Further documents reveal that friars continued to serve Damianus' chapel, as was the case in 1461 (LAT, p. 205).

9 On the basis of later documents, it has been proposed that the chapel was dedicated to the Nativity (Beritić 1956, p. 69; taken up by Benyovsky Latin and Ledić 2014, p. 32).

10 (day unknown)-09-1422 ... dar ali frari minori de Ragusio per officiar la cappella de Sancta Trinita apresso la casa de Lauriça de Volchasso segondo el legatto del ditto Mathio (LAT, p. 201). 
Permission to hold masses in such chapels had to be obtained from the bishop, but, given that the Archives of the Archbishopric burned down in the fire that followed the disastrous earthquake of 1667, these documents are not available. Thankfully, some licences were recorded in notarial series, such as the permission granted to Jacobus Sorgo (d. 1401; cf. Vekarić 2015, pp. 165-66) at the closing of the fourteenth century, for the newly built Trinity chapel (the titular obviously fashionable among Ragusan noblemen). The cathedral chapter, represented by Deacon Dominicus Ribiça, with the consent of the Archbishop Petrus, conceded the right to hold masses and divine offices in the ecclesia seu cappella, built by Sorgo next to the communal wells (but apparently not attached to his house). According to the dedication ritual, which is described in detail, the cornerstone of the future Trinity chapel was to be blessed by the bishop in the Ragusan cathedral and laid in the ground at the future construction site of the chapel. Once the chapel was finished, the episcopal permission to hold masses was to be displayed in the church and sealed in red wax. The seal is precisely described in the licentia: its upper zone was occupied by the Virgin and Child, the central one by three unnamed saints, and the lower by a kneeling bishop and other insigniae (Div. Not., 10, fols. 133rv). ${ }^{11}$ A corresponding dedication practice can therefore be envisaged for other undocumented cases.

The most puzzling instance of privately owned oratories are the "domestic" chapels of Andreas Volzio (d. 1429). ${ }^{12}$ Tuscan humanist Philippus de Diversis, in his "Description of Ragusa" (1440), informs us that this prominent nobleman visited the Holy Land twice. Upon returning from these pilgrimages, Volzio commissioned a pair of Holy Sepulchre replicas: one in domo propria in the city, and the second one in "one of his beautiful gardens", located outside the city walls (de Diversis 2004, p. 183). ${ }^{13}$ Since both Volzio's chapels, erected ad similitudinem sanctum sepulcrum domini Jhesu, have perished, it is unknown whether their layouts reproduced the forms of the actual Holy Sepulchre. Although one could assume that both chapels were used privately, further information provided by Diversis attests to varied uses, regardless of their spatial context. The garden chapel, for instance, was frequented by numerous priests, which were hosted by Volzio "to the glory of the Saviour" (de Diversis 2004, p. 183).

In short, the case of Volzio's chapels, like the ones already discussed, palpably attests to how "domesticity" - a term that can be applied both to a (private) home and a garden -is rather slippery in discussion of these edifices (cf. Garnett and Rosser 2019, pp. 45-46). ${ }^{14}$ These hereditary cappellae and

11 Venerabilis vir Dominicus de Ribiça canonicus ecclesiae Ragusinae se confitetur quod in MCCCLXXXVI indictione VIIII die septimo Junii, dum tunc temporis esset vicarius in tempore liberis et spiritualibus reverendi in Christo patris et domini, domini fratris Petri dei et apostolice sedis gratia, archiepiscopi Ragusini, ut patet per publicum infrascriptum scripti manu Theodori Scolmafogia de Brundisio presens imperiali auctoritate notari et tunc juramentis notarius et cancellarius comunis Ragusii anno domini MCCCLXXVIIII indictione secunda die quinto mensis novembris, a me notario infrascripto iusum, lectum et plenarie intellectum dedit, cessit et concessit nobili viro ser Jacobo de Sorgo liberam licentiam et autoritatem et consensum virtute dicti vicariatus hedificandi et construendi unam ecclesiam seu capellam principaliter sub vocabulo et nomine Sancte et indivindue Trinitatis in dyocesi Ragusi et civitate iuxta puteum comunis qui dicitur illorum de Zrieva, et cum fuerit edificata in ea celebrari faciendi solemnia missarum et divina officia que in sacrosanctis aliis bulatum bulla pendenti ad cordulam facta in cera nova et ab intra cum cera rubea in cuius scultura et figura beate Virginis cum filio in superiori parte, in medio tres figure sanctorum et in inferiori parte figura unius episcopi genuflexi, cum insignis a parte. Cum niuno interferi quibus melius potuit et valuit ad augmentum divini cultus ecclesiis celebrantur, et hec licentia concessa est dicto ser Jacobo presenti et in stante petenti dicatam licentiam sibi concedi, presente reverendo in Christo patre fratre Petro ordinis minorum dei et apostolice sedis gratia episcopo soacensis epiri primum lapidem in dicta ecclesiae benedixit (et dompno Petro caput apis cancell.) in ecclesia Sancte Marie maioris et dompno Petro caput apis qui dictum lapidem portavit et in fundamento posuit ac domino Blasio dicto Vlacota Janice et aliis pluribus presentibus concessioni dicte licentie tunc facte seu concesse in quorum omnium testiomonium et cuiusdam veritatis dictus dyaconus Dominicus presens instrumentum scribi iussit et sigilli sui tunc vicariatus aprendere muniri. Presentibus nobilibus iuris ser Petro de Saracha iudice et ser Volço de Babalio testes.

12 His biography, including important duties he carried out, can be found in (Vekarić 2015, pp. 264-65).

13 (...) Andreas Martoli de Volzio nobilis (...) qui cum bis visitasset sanctum sepulcrum domini Jhesu, illius similitudinem Ragusii in domo propria studit hedificare, et extra urbis moenia apud quoddam eius tunc pulcrum viridarium, ubi saepis sacerdotes congregans eos honore Salvatoris nostris pascebat. This instance was briefly discussed in the context of garden architecture and design in late medieval and early modern Dubrovnik, by (Šišić 2008, pp. 50-52).

14 This is further corroborated by the arrangements made by Andreas' son, Johannes, for the chapel dedicated to St Nicholas of Tolentino in 1459. The chapel, erected to honour the recently canonised saint (1446), was also located in the courtyard of his house (but inside the walls). However, the chapel was not in any way "private" or "household"; fifteenth-century sources attest that a group of tertiaries resided there, and the chapel was, in fact, adjoined to the hospital, founded in 1451 (Beritić 1956, pp. 56-57). 
ecclesiae, founded and upkept by distinguished families—even when adjoined to houses and built on the private land-could have been accessible to different and diverse audiences. After all, accessibility to such structures is linked to the commissioner's need to enhance their household prestige and secure that their souls are adequately prayed for. The conflation of public and private can also be seen in family altars, in churches where donors merged their spiritual needs with (similar) sophisticated representational strategies (cf. Bacci 2009; Murat 2014). To put it simply, hereditary chapels would not have fulfilled their purpose if they had been restricted to household members alone.

\section{Indoor Domestic Spaces and Holy Images: Iconographies and Uses}

According to the sources analysed, freestanding chapels, being limited to the social elite, were rather rare. Domestic devotional spaces, generally speaking, were confined within the walls of houses, and such examples can be found in the dwellings of urban nobility and commoners alike. For instance, in 1491, three perpers for illuminating the chapel in la casa of Dime Benessa (d. 1403), bought by Franciscus Benessa, were transferred to the altar of St Anthony in the chapterhouse of the Franciscan friary (LAT, p. 287). ${ }^{15}$ That is, the bequest for lighting a domestic church ended when the house in which it was located changed owner. In all likelihood, the chapel in the house was a room adapted to the purposes of an oratory. Apart from such rooms-chapels, devotional spaces could have been located in the courtyards. For instance, Trippe Bona, in his testament of 1463, bequeathed 40 perpers for an image of the Nativity (la istoria dela natividade del nostro Salvator) to be placed on the altar of the courtyard chapel of his caxa grande. ${ }^{16}$ The structure is referred to as capella pizola, which could imply that it was a chapel of a reduced size, most likely smaller than the ones of the Volcassio brothers, conceivably similar to the street tabernacle-like shrines that are still in place in virtually every Mediterranean city (cf. Muir 1989).

The most commonplace in-door arrangement that formed the sacred spot of houses-a devotional image protected by wooden cupboards of tabernacle-like appearance-was customarily called glesiola, a vulgarised derivative of Latin ecclesiola, literally "small church" or a "chapel". ${ }^{17}$ The contracts for such structures are rather sparsely recorded, as the structures were accessible wooden caskets, produced serially and therefore not commissioned for specific spaces and patrons. There are, nevertheless, notable exceptions. In 1369, Master Johannes Pavesarius stipulated a contract with Martinus Sorgo to deliver duas glesiolas, one smaller and the other one larger (Tadić 1952, vol. I, p. 16, doc. 48). Both glesiolae were to be painted with azurite, gilded, and ornamented with precisely 51 painted stars. ${ }^{18}$ The two decorated cupboards for holding devotional objects were commissioned for a rather modest price of six ducats. ${ }^{19}$ Given that no specific images or iconographies are mentioned in the contract, it could be presumed that Sorgo asked for a new chest for images he already possessed. There are indications that such decorated structures did not necessarily hold only one sacred object. The list of possessions of a certain Calea Greca, compiled after her death in 1382, mentions a "chest" with no less than four devotional images (una glesiola cum quatuor anconellis inter), (Div. Canc. 25, fol. 143r). ${ }^{20}$

15 1491. adi 19 giuglio. Ser Dragoie de ser Aluvise de Gozze de dar, come apar in diversse de nottaria sotto questo di, li perperi tre che se pagavano per el ditto ser Dragoie per aluminare la capela in la caxa de ser Dime de Benessa, comprada per ser Francisco St. de Benessa, sono apicade al altar de santo Antonio de Padua apresso la sepultura di quelli de Benessa in capitulo delo convento de San Francisco.

16 Voglio et ordino che in nostra capella existente in lo cortivo nostro dela caxa grande sia facta una inchona allo altare della capella pizola che io fexi construere de iperperi XL, et sia la istoria dela natividade del nostro Salvator.

17 It is important to note that Venetian documents of the same time almost exclusively employ the simple term "chest" (armarol, or armarol de santi), (Valenzano 2018, p. 29; Coccato 2018, p. 159). For general observations on the terminology of Florentine material, see (Schmidt 2005, pp. 50-63).

18 [facere] duas glesiolas: 1 magnam et aliam parvam, videlicet de faciendo ipsas glesiolas depingi de açuro fino, et retaies unum depingere de açuro fino et aliud cum auro de duchato. Et ponere stellas LI dictis II glesiolas copertas de auro fino.

19 For an examination of prices in fourteenth-century Ragusan painting, see (Fisković 1983).

20 In late fifteenth- and sixteenth-century records, such ensembles are more rarely referred to as "revetment" of anconae: clausura, clissura or glissura (Tadić 1952, vol. I, p. 236, doc. 487; vol. II, p. 28, doc. 804, 32, doc. 818, 97-98; Fisković 1990, pp. $149-50$, doc. 978). 
In the fifteenth century, preserved contracts regularly describe simultaneous commission of images for devotional purposes and their correspondent cupboards. In 1443, prolific Ragusan painter Johannes Ugrinovich Zornea (Ivan Ugrinović) agreed to craft a wooden tabernacle (capela) containing three unnamed (saintly) figures (Tadić 1952, vol. I, p. 138, doc. 299). ${ }^{21}$ From this, it is reasonable to deduce that the commissioner, Nicolaus Bona, ordered a triptych, the prevailing design of medieval domestic imagery. ${ }^{22}$ The central field most likely represented the Virgin and Child (the other, less likely, option, is the commissioner's name-saint) while the other two figures were depicted on the inner sides of the shutters. Several years later, Ugrinovich's son, Stephanus, stipulated an analogous contract with Radissa Goicich by agreeing to craft an image of an unspecified subject (using gold, azurite, and other colours, ad laudem cuiuslibet magistri), which was incorporated in a wooden jesiola, designed by a carpenter named Petrus. ${ }^{23}$

Although these later documents reveal much about the process of commissioning and designing such devotional structures, they offer no information on their subject matter. In a similar way, household inventories, when referencing these compositions, do not comment upon their iconography, but their condition and aesthetic quality; appellations that are given are beautiful (ancona pulcra), gilded (a. deaurata), small (anconetta, a. pizola), sizeable (a. granda), etc. The term ancona greca (or alla greca / a modo greco), that has received notable attention in recent years, with regard to the devotional potential of archaizing images (Nagel and Wood 2010; Drandaki 2014; also-in the Ragusan context-Demori Staničić 2013), starts occurring in the sources only from the beginning of the sixteenth century. ${ }^{24}$

Notarial records do not specify where exactly these shrines were located, or how they were displayed-for instance, if they were hung on a wall or placed on a horizontal surface. Nevertheless, there are clues regarding the typical location of these domestic shrines in Ragusan houses, notably in references to anconae and giesiolae "da camera". ${ }^{25}$ Camera could refer to any room in the house, but the most reasonable choices are the sala grande and the bedchamber. Indeed, evidence exists for (at least) two sacred images in houses. The most illustrative example is the house of Antonius de Primo, which cherished two figurae della Madonna: one in prima camera and the other one in camera de sopra (Tadić 1952, vol. II, p. 28, doc. 801). Contrary to the situation in Florence-where devotional works were almost exclusively located in sleeping spaces (Wilkins 2002, p. 377)—evidence from Venice attests to a different placement of such images (Morse 2007, p. 161). Importantly, these "multiple locations of devotion" were not confined to spaces strictly for personal use (such as bedrooms), but to the receiving areas of homes as well (Morse 2007, pp. 161-62).

In Venetian houses and palaces, the places of devotion were often porticos (Morse 2013b). In Ragusa it was sala grande, commonly the first floor of the house. The simultaneous commissioning of two cupboards (as in the quoted case of Martinus Sorgo) is the strongest evidence of the location of such shrines in more than one room of the house. Given that the glesiolae commissioned by Sorgo differed in size, it is possible to speculate that the smaller one was intended for the bedroom, while the larger one could have occupied a more prominent and spacious place in the house of this noble family, arguably their sala grande. There are indications-albeit later-of sacred images in other parts of houses, such as the una incona dela Madonna dorada, that was hung in the kitchen (Tadić 1952, vol. II,

21 [facere] unam capelam, ligni intagliatam, de qua ipsi convenerunt ad invicem, videlicet, pulchram et laudabilem cum tribus figuris.

22 Although no example from the period in question has survived, the typology has persisted well into the modern period, see, for instance, (Gamulin 1991, pp. 68-69).

23 [facere] unam anchonam de auro fino et azuro fino et coloribus finis ad laudem cuiuslibet magistri, omnibus expensis eiusdem Stepani, et circumcirca ipsam anconam et quadrum facere jesiolam pulchram et firmam. Que anchona debet esse ad ilam mensuram, videlicet altitudinem, longitudinem et altitudinem (!) quam ordinabit Petar marangonus.

24 For instance, una figura mia alla greca, bequeathed in 1508 (Tadić 1952, vol. II, p. 33); for other contemporary denominations of domestic images, see (Musacchio 2000, p. 151; Morse 2007, p. 159). Images alla greca in Adriatic cities have received significant attention in this volume by (Voulgaropoulou 2019, pp. 14-19).

25 [inaurare] unum quadrum seu unam anchonam cum ecclesiola a camera, de bono opere et fino auro (Tadić 1952, vol. I, pp. 168-69, doc. 357), and unum quadrum de camera cum casselleta magnum et pulchrum (... ) et bene intagliatum quantum dare possit (Tadić 1952, vol. I, pp. 198-99, doc. 414). 
p. 33 , doc. 823). ${ }^{26}$ After all, the movability of objects and chests of reduced size made it possible to relocate them according to the needs and wishes of household members, just as the sacred content of wooden cupboards could have been replaced with new devotional objects (not necessarily images, as shall be discussed below).

A surviving example offers a glimpse into what these domestic images might have looked like. The Madonna and Child (Figure 2), attributed to Blasius de Tragurio (Blaž Jurjev Trogiranin), is an emblematic painting for the purposes of personal devotion. The restoration work has proven that the outer rectangular frame is original, so the image was not supplied with hinged wings, but it could have been included in tabernacle-like structures (Demori Staničić 1986, p. 86). More importantly, the intimate iconography underlies the close connection between the Mother and Child, typical of domestic holy images. This small ancona attunes with the advice given by Giovanni Dominici in his Regola del governo familiare of 1403, in regard to the use of religious images in the upbringing of children: "It is well to have the Virgin Mary with the Child in arms, with a little bird or apple in His hand. There should be a good representation of Jesus nursing, sleeping, in His Mother's lap or standing courteously before her while they look at each other" (cited as in Musacchio 2000, pp. 147, 152). These instructions-routinely quoted in reflections on the use of objects of personal devotion-firmly place such props in the realm of "devotional pedagogy" - the moral and religious training of children (Van Os 1994, p. 91; Klapisch-Zuber 1998, p. 117; Johnson 2002).

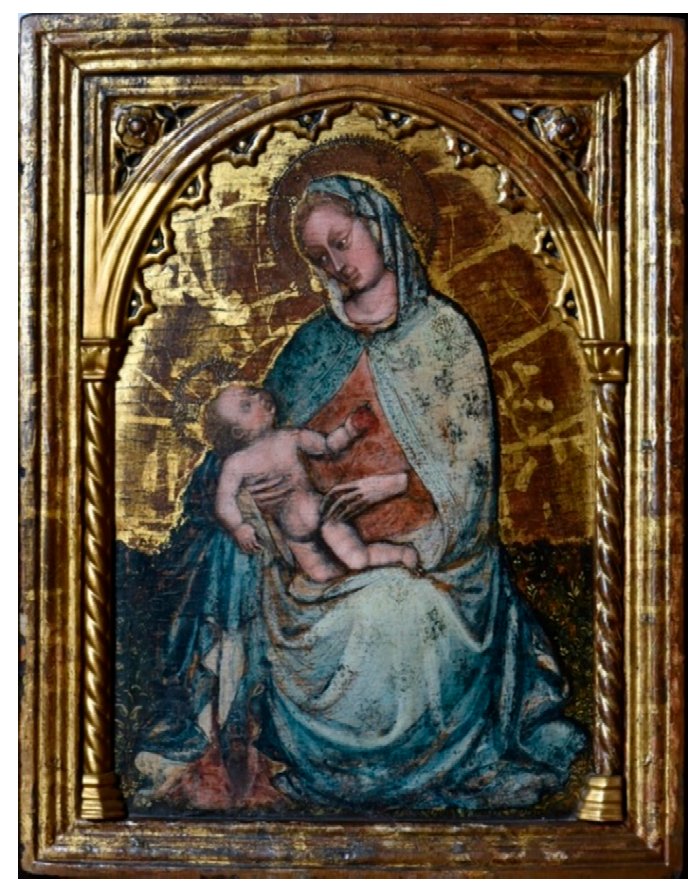

Figure 2. Blaž Jurjev Trogiranin, Madonna with Child, ca. 1421-27, tempera on wood, $64.5 \times 49.7 \mathrm{~cm}$, Bishop's Palace, Dubrovnik (photo by Božidar Gjukić).

Some of these domestic anconae were more complex, as they followed the design of church altarpieces. Besides the most radiated forms-that of a triptych or image of elementary rectangular frames-there also existed domestic panels depicting a number of saints (not necessarily in larger formats). For instance, a panel commissioned in 1440 by Michael Zamagno (from Johannes Ugrinovich), measuring $1.25 \mathrm{~m}$ in width and $1.13 \mathrm{~m}$ in height, was supposed to accommodate no less than ten saintly figures with gilded halos (Tadić 1952, vol. I, pp. 110-11, doc. 246), probably arranged in two

26 This inventory of the house of Catha, a Clarissa nun, also mentions another image, una figura de gisso tuta in una cassa depenta in sala. 
registers. ${ }^{27}$ An equally important parallel with paintings mounted on church altars was the practice of coverage, either by shutters or curtains (cf. Schmidt 2007). ${ }^{28}$ Further correlation between altarpieces in churches and those at home can be drawn from secondary visual sources, which pair domestic images with oil lamps, candles, or containers of holy water (Schmidt 2005, pp. 95-96; Morse 2007, pp. 166-69). The household image was, after all, a sacred object that was to be treated equally to those in churches. This attests to how the "laity appropriated the liturgical practice of the clergy to frame the sacred within their own home" (Cooper 2006, p. 193). In such a way, these domestic images were activated only at certain times, in moments of personal or familial prayer. However, no record from Ragusan archives thus known references an altar inside the house, including consecrated stones (pietra sagrata), on which mass could have been said (cf. Mattox 2006). The altars, accordingly, seem to have been confined to a handful of free-standing chapels with the permission to celebrate mass-such as those owned by the Volcassio, Volzio and Sorgo families.

When observing the uses of sacred installations in households, one should not fail to acknowledge the seemingly insignificant fact that they were defined as "small churches". This term is used sparingly in contemporary sources in other Adriatic cities and can, therefore, be considered a peculiarity of Ragusan documents. ${ }^{29}$ The ecclesiola/gliesiola/jesiola, apart from being a rather dry term for a range of devotional structures, was also a synonym for family in medieval Christian thought, deriving from the writings of the Church fathers (cf. Novotný 2013). In other words, the very name of the domestic shrines in question is in line with their uses, and with typically domestic iconographies. What is more, the role of the father of the family, responsible for the "organisation of religious life of his domestic community," was equated with that of a bishop (Widok 2013, pp. 170-72). All this could potentially explain not only the terminology employed, but also the emulation of forms of church altarpieces in domestic installations, which were devotional foci in dwellings and, at the same time, instruments in the religious and moral upbringing of children (Lawless 2014-2015, pp. 64-65). We should not fall into the trap of seeing domestic interiors as exclusively secular spaces (Morse 2007, p. 184); the use of devotional images was manifold, bringing together the need for the sanctification of homes and personal devotion with that of pedagogy. In this way, the small-scale domestic images, often discredited when observed against more lavish forms of church art, were the point of convergence of everyday religious experience.

\section{Privately Owned Relics}

Paintings were but one facet of the domestic culture of religion (cf. Sorelli 2001). The final part of the paper will thus briefly deal with domestic relic collecting. In general, all devotional objects were kept in chests, and occasionally incorporated into the already discussed domestic ecclesiolae. In his testament of 1442, the priest Gon Meliz from Durrës, Albania, bequeathed his casaleta e la incona e zo ch'e dentro de la caseleta, e la ghiesiola de la incuna (Tadić 1952, vol. I, p. 132, doc. 287). The formulation, "an image with other belongings in the casket," implies that several objects were stored in the chest, presumably relics or utensils for performing mass (the owner was, after all, a presbiter). Another possibility for the display of relics in households, somewhat more sophisticated, was to enshrine them in a cross (Anderson 2007, p. 117). There are a number of such references in sources, for instance, una

27 [fare] una anchona de longeza et alteza, come appar de soto, et che sia in la deta anchona santi X, como appar de soto [alta bracia $2 \frac{1}{4}$, larga brazia $2 \frac{1}{2}$ ]. Et che debia lo detto Zornella servir ben de color et de belle figure, zoe alo compartimento de soto, et le diademe far tute d'oro et li drapi de santi adornati d'oro come apartien.

28 These covering devices, however, were only occasionally recorded in sources, for instance un anchona con la cortina in the inventory of goods of Rusa, wife of Milovat Pribinich (Tadić 1952, I, p. 239, doc. 499). In his extensive archival work, Tadić was exclusively interested in "visual arts", which is why the excerpts he published from private do not acknowledge the candelabra that illuminated images. Inventories from other cities reveal that these accessories were conventional (Musacchio 2000, p. 150; Schmidt 2005, pp. 95-96).

29 For instance, liturgical utensils in Venice in the shape of minuscule church architecture were termed ecclesiola or chiesola (Dale 2010, p. 180), whilst Florentine sources use cappellanuccio / chapellinaiusso, a simple shrine (Palmer 2001, p. 78). 
croce parva argentea cum reliquiis, owned by Ratcho Priach in 1387 (Div. Canc. 25, fol. 155v). However, it is impossible to ascertain whether these were small pectoral crosses that contained particles of relics (for apotropaic and talismanic purposes) or house crosses, displayed in domestic settings similarly to other devotional artworks.

Personal inventories and last wills do not specify which relics were owned by individuals, but some evidence exists regarding private relics of the Holy Cross, owned by prominent families in the fourteenth century (namely Bona and Menze), although the subsequent whereabouts of these domestic relics are unknown (Lonza 2009, p. 290). Recent research has shed much-needed light on the city's most prominent relics (cf. Munk 2016; Trška 2017; Zelić and Viđen 2018), yet our knowledge of the importance of the private initiative in procuring them is still lacking. In fact, the information regarding relics in private hands, more often than not, derives from the time of their donation to church treasuries (otherwise, they would have remained unrecorded). ${ }^{30}$ However, we know that the most popular relics were connected to pilgrimages, either renewed spiritual journeys to Rome or the Holy Land, or some other local pilgrimage centre. In fact, pilgrims traveling to these important sacred sites often brought back a number of secondary and contact relics related to the locations of sacred events and places associated with the life of Christ (Gertsman and Mittman 2017).

An illustrative case is that of Marussa of Priboie, whose recently published testament (Lonza 2019, pp. 56-60) references the following objects: seven reliquary boxes (scatulae magnae/parvae), five Jericho roses, eight vials of water from the Jordan River, and ropes used to measure the dimensions of the sacred edifices (Lonza 2019, pp. 58, 61-63). ${ }^{31}$ Marussa's case shows how the familial (and, in this particular instance, gender) dimensions of the phenomenon were crucial-a group of women financed her pilgrimage, and she bequeathed all of her domestic devotional props to neighbours and her aunt, while the most precious among them (boxes containing relics) were given to daughters of her epitropa (Lonza 2019, pp. 42-43). Marussa, therefore, bequeathed a set of objects that were procured during a spiritual pilgrimage to the Holy Land to members of her family, and these sacred memorabilia must have been stored in proximity to other holy objects in households.

\section{Conclusions}

The archival sources discussed in this paper offer valuable insight into the appearances of sacred spaces in late medieval households of Ragusa, of the urban elite and general population alike. The evidence gathered here reveals multiple levels of familial influence on domestic devotional practices. The hereditary rights of chapels, constructed by prominent families, perpetuated the memory of their founders, and, although constructed on private terrain and privately funded, they were places of public veneration, as well. These structures were the most lavish form of domestic devotion, not only by virtue of their size, but also as a key strategy in securing the salvation of the souls of their founders and heirs. Indoor foci of prayer were equally elaborate, and a number of their features-such as the use of curtains and shutters to cover holy images, and the emulation of church altarpiece formats-testifies to the adoption of liturgical elements into domestic religious practice. This one-way influence of institutional religion on household practices is only one side of devotional practices for, as attested by later sources, a number of domestic devotional objects-due to their devotional potential and miraculous powers-passed over from domestic to public church spaces (cf. Voulgaropoulou 2019, pp. 25-32). Indeed, this interplay between the private and the public was determinant to the experience and use of the urban, household and garden chapels discussed, given that they served purposes of

30 For discussion on domestic images that have made their way to church altars, see (Voulgaropoulou 2019, pp. 25-33), for the use of donated relics in public rituals of Adriatic towns see recent discussion by (Ulčar 2015, pp. 101-3).

31 Volo quod detur una scatula Margarite filie Ruse et una alia Nicolete sorori sue scatula parva. Et Ruse detis unam craniçam seu cordellam cum qua mensuravi sepulcrum Christi et unam rusam et unam scatulam date Cuite vicini mee que stat ad parietem domus mee et unam craniçam et fili quibus consuitur quia eius sunt. Et detis unam scatolam Lubne quam vos vultis et craniçam unam et unam rosam, et unam scatulam Miladne Gradoevich que non est pulcra. (. . ) Et date scatulam unam Goyne Velegni (?) miscitari (?). Et Ratche vicine mee dare unam uram (?) sive cimossem de scarleto que tetigit omnia loca Terre Sancte et unam rosam que est minor. 
religious and moral education, as well as their owner's representation. In this sense, one of the most promising avenues for future research is to observe the ecclesiae and ecclesiolae more attentively in the context of interfamilial networks, in order to gain a more nuanced insight into their hereditary and domestic contexts.

Funding: This research received no external funding.

Acknowledgments: I would like to thank Salvador Ryan for inviting me to participate in the special issue of Religions journal "Domestic Devotions in Medieval and Early Modern Europe". Ana Marinković helped me with Latin transcriptions; Ivan Viđen kindly provided me with photographs and offered valuable help during my research stay in Dubrovnik. I am also grateful for the comments offered by the anonymous reviewers.

Conflicts of Interest: The author declares no conflict of interest.

\section{Abbreviations}

HR-DADU State Archives in Dubrovnik (Državni arhiv u Dubrovniku)

Div. Not. HR-DADU-9 Diversa Notariae

Div. Canc. HR-DADU-15 Diversa Cancellariae

Vend. Canc. HR-DADU-16 Venditiones Cancellariae

LAT

Zelić, Danko (ed.). Knjiga rizničarskih najmova = Liber affictum thesaurarie (1428-1547).

Zagreb and Dubrovnik: HAZU and Zavod za povijesne znanosti u Dubrovniku, 2012.

\section{References}

\section{Primary Sources}

Državni arhiv u Dubrovniku (Dubrovnik State Archives)

(Div. Not.) HR-DADU-9 Diversa Notariae, vol. 10.

(Div. Canc.) HR-DADU-15 Diversa Cancellariae, vol. 25.

(Vend. Canc.) HR-DADU-16 Venditiones Cancellariae, vol. 4.

(Čremošnik 1951) Čremošnik, Gregor, ed. 1951. Spisi dubrovačke kancelarije, vol. I. Zapisi notara Tomazina de Savere 1278-1282. Zagreb: JAZU.

(Lučić 1993) Lučić, Josip, ed. 1993. Spisi dubrovačke kancelarije, vol. IV. Zapisi notara Andrije Beneše 1295-1301, Praecepta rectoris II (1299-1301), Testamenta II (1295-1301). Zagreb: HAZU, Zavod za hrvatsku povijest and Filozofski fakultet.

\section{Secondary Sources}

Anderson, Caroline Corisande. 2007. The Material Culture of Domestic Religion in Early Modern Florence, c. 1480-c. 1650. Ph.D. dissertation, University of York, York, UK.

Bacci, Michele. 2009. Side Altars and Pro Anima Chapels in the Medieval Mediterranean: Evidence from Cyprus. In The Altar and its Environment, 1150-1400. Edited by Justin E.A. Kroesen and Victor M. Schmidt. Turnhout: Brepols, pp. 11-30.

Bacci, Michele. 2018. Devotional Panels as Sites of Intercultural Exchange. In Domestic Devotions in Early Modern Italy. Edited by Maya Corry, Marco Faini and Alessia Meneghin. Leiden and Boston: Brill, pp. 272-92.

Baldissin Molli, Giovanna, Cristina Guarnieri, and Zuleika Murat, eds. 2018. Pregare in casa. Oggetti e documenti della pratica religiosa tra Medioevo e Rinascimento. Rome: Viella.

Belamarić, Joško. 2018. Biskupska palača u Dubrovniku. Dubrovnik: Dubrovačka biskupija.

Benyovsky Latin, Irena, and Stipe Ledić. 2014. The Estate of the Volcassio Family in Medieval Dubrovnik. Dubrounik Annals 18: 7-45. [CrossRef]

Beritić, Lukša. 1956. Ubikacija nestalih gradjevinskih spomenika u Dubrovniku. Prilozi povijesti umjetnosti u Dalmaciji 10: 15-83.

Coccato, Stefania. 2018. Oggetti, documenti e spazi devozionali privati nei palazzi veneziani del XIV secolo. In Pregare in Casa. Oggetti e Documenti Della Pratica Religiosa tra Medioevo e Rinascimento. Edited by Giovanna Baldissin Molli, Cristina Guarnieri and Zuleika Murat. Rome: Viella, pp. 149-61. 
Cooper, Donal. 2006. Devotion. In At Home in the Renaissance. Edited by Marta Ajmar-Wollheim and Flora Dennis. London: V\&A Publications, pp. 190-203.

Dale, Thomas. 2010. Cultural Hybridity in Medieval Venice: Re-Inventing the East at San Marco after the Fourth Crusade. In San Marco, Byzantium and the Myths of Venice. Edited by Henry Maguire and Robert S. Nelson. Washington, DC: Dumbarton Oaks Research Library and Collection, pp. 151-91.

de Diversis, Filip. 2004. Opis slavnoga grada Dubrovnika. Edited and translated by Zdenka Janeković Römer. Zagreb: Dom i svijet.

Demori Staničić, Zoraida. 1986. Cat. no. 3-Bogorodica s djetetom. In Blaž Jurjev Trogiranin: Exhibition catalogue. Zagreb: MTM, p. 86.

Demori Staničić, Zoraida. 2013. Ikona Bogorodice s Djetetom iz crkve Sv. Nikole na Prijekom u Dubrovniku. Ars Adriatica 3: 67-84. [CrossRef]

Drandaki, Anastasia. 2014. A Maniera Greca: Content, Context and Transformation of a Term. Studies in Iconography 35: 39-72.

Fisković, Igor. 1983. Dubrovačko slikarstvo i društveni okviri njegova razvoja u XIV stoljeću. Prilozi povijesti umjetnosti u Dalmaciji 23: 75-147.

Fisković, Igor. 1990. Tipologija i morfologija oltarnih slika 15. stoljeća u Dalmaciji. Prilozi povijesti umjetnosti u Dalmaciji 29: 113-55.

Fisković, Igor. 1997. Crkvica Sv. Kuzme i Damjana u središtu Dubrovnika. Dubrovnik 8: 261-75.

French, Katherine L. 2014. Localized Faith: Parochial and Domestic Spaces. In The Oxford Handbook of Medieval Christianity [Oxford Handbooks Online]. Edited by John H. Arnold. Oxford: Oxford University Press, pp. 1-12.

Gamulin, Grgo. 1991. Pseudo-Victor, triptih u Dubrovniku. Peristil 34: 67-68.

Garnett, Jane, and Gervase Rosser. 2019. The Ex Voto between Domestic and Public Space: From Personal Testimony to Collective Memory. In Domestic Devotions in Early Modern Italy. Edited by Maya Corry, Marco Faini and Alessia Meneghin. Leiden and Boston: Brill, pp. 45-62.

Gertsman, Elina, and Asa Simon Mittman. 2017. Rocks of Jerusalem. Bringing the Holy Land Home. In Natural Materials of the Holy Land and the Visual Translation of Place, 500-1500. Edited by Renana Bartal, Neta Bodner and Bianca Kühnel. New York: Routledge, pp. 157-71.

Grujić, Nada. 2013. Kuća u Gradu: Studije o dubrovačkoj stambenoj arhitekturi 15. i 16. stoljeća. Dubrovnik: Matica hrvatska-Ogranak Dubrovnik.

Hilje, Emil. 2000. Slikarska djela u sačuvanim inventarima zadarskih građana iz 14. i 15. stoljeća. Radovi Zavoda za povijesne znanosti HAZU u Zadru 42: 65-78.

Howard, Deborah, Maya Corry, and Mary Laven, eds. 2017. Madonnas E Miracles: The Holy Home in Renaissance Italy. London: Philip Wilson Publishers.

Johnson, Gerardine A. 2002. Beautiful Brides and Model Mothers: The Devotional and Talismanic Functions of Early Modern Marian Reliefs. In The Material Culture of Sex, Procreation and Marriage. Edited by Anne L. McClanan and Karen Rosoff Encarnación. New York: Palgrave Press, pp. 135-61.

Kasl, Ronda. 2004. Holy Households: Art and Devotion in Renaissance Venice. In Giovanni Bellini and the Art of Devotion. Edited by Ronda Kasl. Indianapolis: Indianapolis Museum of Art, pp. 59-89.

Klapisch-Zuber, Christiane. 1998. Holy Dolls: Play and Piety in Florence in the Quattrocento. In Looking at Italian Renaissance Sculpture. Edited by Sarah Blake McHam. New York: Cambridge University Press, pp. 111-27.

Kolpacoff Deane, Jennifer. 2013. Medieval Domestic Devotion. History Compass 11: 65-76. [CrossRef]

Lawless, Catherine. 2014-2015. Sensing the Image: Gender, Piety and Images in Late Medieval Tuscany. Open Arts Journal 4: 61-74. [CrossRef]

Lonza, Nella. 2009. Kazalište vlasti: Ceremonijal i državni blagdani Dubrovačke Republike u 17. i 18. stoljeću. Zagreb: HAZU-Zavod za povijesne znanosti u Dubrovniku.

Lonza, Nella. 2012. For the Salvation of the Souls, for the Welfare of the State: Ragusan Treasurers and Perpetual Trusts for Pious Purposes from the Thirteenth to the Fifteenth Century. In Knjiga rizničarskih najmova/Liber affictum thesaurarie (1428-1547). Edited by Danko Zelić. Zagreb: HAZU-Zavod za povijesne znanosti u Dubrovniku, pp. 25-41.

Lonza, Nella. 2019. Ego fui per omnia loca sancta: Maruša of Dubrovnik and her pilgrimage to the Holy Land in 1394. Dubrovnik Annals 23: 37-63. [CrossRef]

Lydecker, John Kent. 1987. The Domestic Setting of the Arts in the Renaissance Florence. Ph.D. dissertation, John Hopkins University, Baltimore, MD, USA. 
Mattox, Philip. 2006. Domestic Sacral Space in the Florentine Renaissance Palace. Renaissance Studies 20: 658-73. [CrossRef]

Morgan, Hollie L.S. 2017. Beds and Chambers in Late Medieval England. Readings, Representations and Realities. York: York Medieval Press.

Morse, Margaret A. 2007. Creating Sacred Space: The Religious Visual Culture of the Renaissance Venetian Casa. Renaissance Studies 21: 151-58. [CrossRef]

Morse, Margaret A. 2013a. From Chiesa to Casa and Back: The Exchange of Public and Private in Domestic Devotional Art. In Reflections on Renaissance Venice: A Celebration of Patricia Fortini Brown. Edited by Maria Blake de and Mary E. Frank. Milan: 5 Continents Editions, pp. 143-53.

Morse, Margaret A. 2013b. The Venetian Portego: Family Piety and Public Prestige. In The Early Modern Italian Domestic Interior, 1400-1700: Objects, Spaces, Domesticities. Edited by Erin J. Campbell, Stephanie R. Miller and Elizabeth Carroll Consavari. Farnham: Ashgate, pp. 89-106.

Muir, Edward. 1989. The Virgin on the Street Corner: The Place of the Sacred in Italian Cities. In Religion and Culture in the Renaissance and Reformation. Edited by Steven E. Ozment. Kirksville: Sixteenth-Century Journal Publishers, pp. 25-40.

Munk, Ana. 2016. Deconstructing the Myth of Byzantine Crown: The Head Reliquary of Saint Blaise in Dubrovnik. Dubrovnik Annals 20: 7-52. [CrossRef]

Murat, Zuleika. 2014. The Tomb of the beato Pacifico in the Basilica dei Frari: Personal Devotion or Public Propaganda? Hortus Artium Medievalium 20: 874-82. [CrossRef]

Musacchio, Jacqueline Marie. 2000. The Madonna and Child, a Host of Saints, and Domestic Devotion in Renaissance Florence. In Revaluing Renaissance Art. Edited by Gabriel Neher and Rupert Shepherd. London: Routledge, pp. 147-59.

Nagel, Alexander, and Christopher S. Wood. 2010. Anachronic Renaissance. New York: Zone Books.

Nalle, Sara. 2008. Private Devotion, Personal Space: Religious Images in Domestic Context. In La Imagen Religiosa en la Monarquía Hispánica. Edited by María Cruz de Carlos, Pierre Civil, Felipe Pereda and Cécile Vincent-Cassy. Madrid: Casa de Velázquez, pp. 255-72.

Novotný, Vojtěch. 2013. History of the Concept Ecclesia Domestica in Theology until the Seventeenth Century. Marriage, Families $\mathcal{E}$ Spirituality 19: 157-85.

Palmer, Allison Lee. 2001. The Walter' Madonna and Child Plaquette and Private Devotional Art in Early Renaissance Italy. The Journal of the Walters Art Museum 59: 73-84.

Prijatelj Pavičić, Ivana. 2011. Prilog proučavanju dubrovačkih molitvenika XV. stoljeća. Prilozi povijesti umjetnosti u Dalmaciji 42: 205-49.

Schmidt, Victor Michael. 2005. Painted Piety. Panel Paintings for Personal Devotion in Tuscany. Florence: Centro Di.

Schmidt, Victor M. 2007. Curtains, Revelatio and Pictorial Reality in Late Medieval and Renaissance Italy. In Weaving, Veiling, and Dressing. Textiles and Their Metaphors in the Late Middle Ages. Edited by Kathryn M. Rudy and Barbara Baert. Turnhout: Brepols, pp. 191-213.

Šišić, Bruno. 2008. Dubrovnik Renaissance Gardens: Genesis and Design Characteristics. Dubrovnik and Zagreb: HAZU, Zavod za povijesne znanosti, Centar za povijesne vrtove i razvoj krajobraza u Dubrovniku, and Agronomski fakultet.

Sorelli, Fernanda. 2001. Oggetti, libri, momenti domestici di devozione. Appunti per Venezia (secoli XII-XV). Quaderni di Storia Religiosa 8: 55-78.

Tadić, Jorjo. 1952. Građa o slikarskoj školi u Dubrovniku XIII-XVI v. Belgrade: Naučna knjiga, vol. I-II.

Trška, Tanja. 2017. Miraculous Image as a Relic: The Reliquary of St Filippo Benizi in Dubrovnik's Cathedral Treasury. Radovi Instituta za povijest umjetnosti 41: 67-81. [CrossRef]

Ulčar, Milena. 2015. Relikvijar Svetog Križa i proslava Uskrsa u Perastu. Radovi Instituta za povijest umjetnosti 39: 99-108.

Valenzano, Giovanna. 2018. Gli spazi della devozione domestica. In Pregare in casa. Oggetti e documenti della pratica religiosa tra Medioevo e Rinascimento. Edited by Giovanna Baldissin Molli, Cristina Guarnieri and Zuleika Murat. Rome: Viella, pp. 15-39.

Van Os, Henk. 1994. The Art of Devotion in the Late Middle Ages in Europe, 1300-1500. Princeton: Princeton University Press.

Vekarić, Nenad. 2012. Vlastela grada Dubrovnika, vol. 3. Vlasteoski rodovi (M-Z). Zagreb and Dubrovnik: HAZU-Zavod za povijesne znanosti u Dubrovniku. 
Vekarić, Nenad. 2015. Vlastela grada Dubrovnika, vol. 6. Odabrane biografije (Pi-Z). Zagreb and Dubrovnik: HAZU-Zavod za povijesne znanosti u Dubrovniku.

Voulgaropoulou, Margarita. 2019. From Domestic Devotion to the Church Altar: Venerating Icons in the Late Medieval and Early Modern Adriatic. Religions 10: 390. [CrossRef]

Webb, Diana. 2005. Domestic Space and Devotion. In Defining the Holy: Sacred Space in Medieval and Early Modern Europe. Edited by Andrew Spicer and Sarah Hamilton. Aldershot: Ashgate, pp. 27-47.

Widok, Norbert. 2013. Christian Family as Domestic Church in the Writings of St. John Chrysostom. Studia Ceranea 3: 167-75. [CrossRef]

Wilkins, David G. 2002. Opening the Doors to Devotion: Trecento Triptychs and Suggestions Concerning Images and Domestic Practice in Florence. In Italian Panel Painting of the Duecento and Trecento. Edited by Victor M. Schmidt. Washington, DC: National Gallery of Art, Center for Advanced Study in the Visual Arts, pp. 371-93.

Zelić, Danko, and Ivan Viđen. 2018. Inventario dela giexia di S. Maria Mazor, de tute le argentarie, aparati deli sazerdoti, insenarii, libri, tapezarie et altre robe (1531.)-najstariji imovnik liturgijske opreme, ruha i paramenata dubrovačke prvostolnice. Radovi Instituta za povijest umjetnosti 42: 19-36.

Živković, Pavo. 1985. Pariteti dubrovačkog novca u srednjem vijeku. Anali Zavoda za povijesne znanosti Istraživačkog centra JAZU u Dubrovniku 32-33: 31-39.

Živković, Valentina. 2016. The Deathbed Experience-Icons as Mental Images. Preparations for a Good Death in Late Medieval Kotor (Montenegro). Ikon 9: 221-30. [CrossRef]

(C) 2019 by the author. Licensee MDPI, Basel, Switzerland. This article is an open access article distributed under the terms and conditions of the Creative Commons Attribution (CC BY) license (http://creativecommons.org/licenses/by/4.0/). 